\title{
Dissolution Kinetics of Stilbite at Various Temperatures under Alkaline Conditions
}

\author{
E. T. Glover*, A. Faanu' and J. R. Fianko' \\ 'National Nuclear Research Institute and 'Radiation Protection Institute, Ghana Atomic \\ Energy Commission, P. O. Box LG 80, Legon-Accra, Ghana \\ Corresponding author; E-mail:etglover2002@yahoo.com
}

\begin{abstract}
Experiments measuring the dissolution rates of stilbite $\left(\mathrm{NaCa}_{2}\left[\mathrm{Al}_{3} \mathrm{Si}_{13} \mathrm{O}_{s,}\right] .14 \mathrm{H}_{2} \mathrm{O}\right)$ in $p \mathrm{H}$-buffered solutions were performed in batch reactors at 4, 25, 40 and $60 \mathrm{C}$. The $p \mathrm{H}$ conditions of the buffer solutions ranged from 8.5 to 12.5. The dissolution rates calculated from silicon concentration of the reacting fluid increased with increasing temperature $\left(4-60^{\circ} \mathrm{C}\right)$ and $\mathrm{pH}$. The dissolution rates ranged from $3.45 \times 10^{-15}\left(\mathrm{~mol} \mathrm{~cm}^{2} \mathrm{~s}^{\prime}\right)$ at $p \mathrm{H} 10.7$ and $4 . \mathrm{C}$ to 1.93 $\mathrm{x} 10^{\circ}\left(\mathrm{mol} \mathrm{cm}^{2} \mathrm{~s}^{\prime}\right)$ at $p \mathrm{H} 12$ and $60^{\circ} \mathrm{C}$ and were $p \mathrm{H}$ dependent. The rate law was established as $\mathrm{R}=k\left(\mathrm{a}_{\text {oi }}\right)^{\circ}$, where $k$ is the rate constant, $\mathrm{a}$ is the activity of the $\mathrm{OH}$ species and $\mathrm{n}$ the reaction order. The $\mathrm{n}$ values obtained were, 0.32 at 4 C, 0.35 at $25{ }^{\circ} \mathrm{C}, 0.38$ at $40{ }^{\circ} \mathrm{C}$ and 0.38 at $60{ }^{\circ} \mathrm{C}$. Activation energy determined using Arrhenius plot was 48.45 $\mathrm{kJ} / \mathrm{mol}$ at $p \mathrm{H} 9$ and $30.88 \mathrm{~kJ} / \mathrm{mol}$ at $p \mathrm{H} 12$.
\end{abstract}

\section{Introduction}

The current design concept for geological repository of radioactive waste involves the use of multiple barriers, both geological and engineered, to isolate and contain the radioactive materials in the waste. The high sorption capacity, low permeability and the ability to condition its repository porewaters to a highly alkaline $p \mathrm{H}$ makes cementitious material an attractive engineered barrier material in the design of a geological radioactive waste repository (Hodgkinson \& Hughes, 1999). The high $p \mathrm{H}$ condition lowers the solubility of a number of radionuclides and slows corrosion of the metallic components of the repository.

Saturation of the repository with ground water will occur during the post closure phase of the repository and dissolution of calcium silicate hydrate, the main constituent of cement will generate a high alkaline environment. The hyperalkaline plume $(p \mathrm{H}$ 12.5-13) will migrate through the repository and into the host geology. It will dissolve the host rock especially the aluminosilicate followed by precipitation of calcium aluminosilicate hydrate, a zeolite. Reaction between the minerals in the host rock and alkaline plume will alter the barrier properties of the host geology. Zeolites have higher molar volumes than most primary silicates in host rock (Savage, 1996) but it is not known whether alternation will result in changes in properties. Therefore, mineral/rock interaction must be studied in order to predict the behaviour and stability of the host rock surrounding a cementitious radioactive waste repository. In this paper the dissolution rates of stilbite, a zeolite investigated under alkaline conditions at different temperatures is presented.

\section{Materials and methods}

Stilbite

Stilbite $\left(\mathrm{NaCa}_{2}\left[\mathrm{Al}_{5} \mathrm{Si}_{13} \mathrm{O}_{36}\right] .14 \mathrm{H}_{2} \mathrm{O}\right)$ is a hydrated sodium calcium aluminum silicate 
of the zeolite group of minerals. Zeolites are crystalline hydrated aluminosilicate minerals of alkali and alkaline earth metals, having infinite three-dimensional atomic structures. The three dimensional structure is based on an infinitely extending framework of $\left[\mathrm{SiO}_{4}\right]^{*}$ and $\left[\mathrm{AlO}_{4}\right]^{*}-$ polyhedral (Fig. 1). These polyhedra are linked by their corners to each other by sharing of oxygen ions to produce an open structural form which has internal cavities in which molecules of various sizes can be trapped (Fig. 2).The structural formula

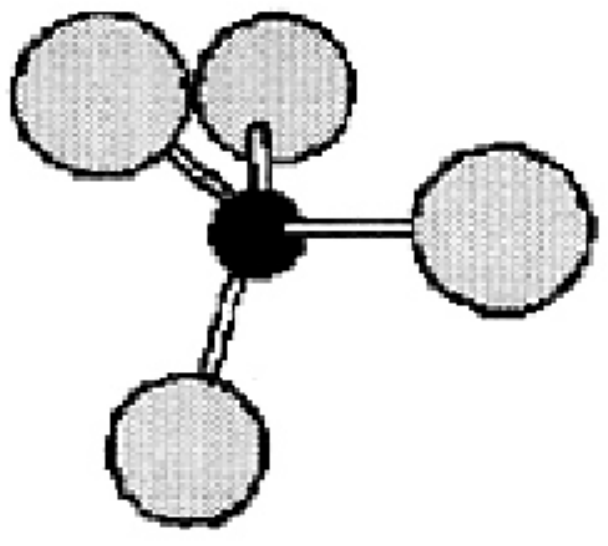

Fig. 1. Three dimensional structure of zeolite

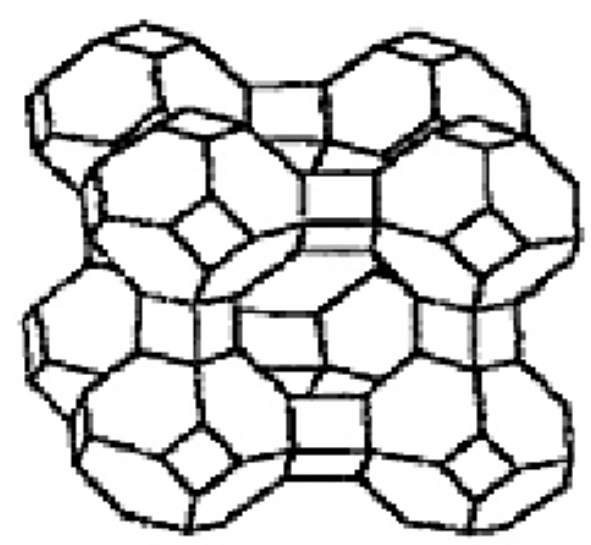

Fig. 2. Structural matrix of a zeolite of zeolite is based on the crystal unit cell, the smallest unit of structure represented by:

$$
\mathrm{M}_{\mathrm{si}}\left[\left(\mathrm{AlO}_{2}\right)_{x}\left(\mathrm{SiO}_{2}\right)_{4}\right] * \mathrm{wH}_{2} \mathrm{O}
$$

where $n$ is the valence of the cation $\mathrm{M}, w$ is the number of water molecules per unit cell, $x$ and $y$ are the total number of tetrahedral per unit cell, and $y / x$ usually has values of $1-5$. The charge imbalance of the zeolite framework structure is balanced out by metal cations, which reside in the open channels in coordination with framework oxygens and water molecules both of which have considerable freedom of movement, permitting ion exchange and reversible dehydration without major change of atomic structure. Zeolites have very low specific gravity of 2.0-2.3.

Stellerite $\left(\mathrm{CaAl}_{2} \mathrm{Si}_{1} \mathrm{O}_{1 \mathrm{~s}}-7 \mathrm{H}_{2} \mathrm{O}\right)$ have the same aluminosilicate framework as stilbite but vary in the $\mathrm{Si} / \mathrm{Al}$ ratio and in concentration and distribution of extra framework cations. In stellerite, due to the absence of $\mathrm{Na}$, only one extraframework site is present whereas in stilbite a small number of $\mathrm{Na}$ atoms in a different extra framework site causes the oblique nature of the framework (Quartieri et al., 1987).

\section{Mineral dissolution}

Mineral dissolution in aqueous media is a process controlled by reaction at the mineral surface. According to the surface protonation model, used to describe the dissolution process, the surface hydroxyl groups are protonated or deprotonated with variation in $\mathrm{pH}$ (Chen \& Brantley, 1998). The dissolution rate of minerals is, therefore, dependent on the concentration of the protonated surface sites at $p \mathrm{H}<p \mathrm{H}_{\text {pax }}$ or the deprotonated site at $p \mathrm{H}>p \mathrm{H}_{\text {pans }}$, where $p \mathrm{H}_{\text {pax }}$ stands for $p \mathrm{H}$ of point 
of zero net proton charge, or the $p \mathrm{H}$ at which the concentration of positively charged surface sites equals the concentration of negatively charged surface sites of the mineral (Chen \& Brantley, 2000). The $p \mathrm{H}$ dependence of the rate $\mathrm{R}_{n}$ for proton promoted dissolution of mineral is described by an empirical rate law (Wieland et al, 1988):

$$
\mathrm{R}_{n}=k[\mathrm{H}]^{\circ} \quad \text { (1) }
$$

where $k$ is the dissolution rate constant $\left[\mathrm{H}^{+}\right]$is the $\mathrm{H}$ concentration in the aqueous solution and $n$ is a rational exponent which implies a fractional reaction order.

Dissolution rate of minerals increases exponentially with increasing temperature as described by Arrhenius equation

$$
k=\operatorname{Aexp}\left(-\mathrm{E}_{\mathrm{a}} / \mathrm{RT}\right)
$$

where $k$ is the dissolution rate constant, $\mathrm{A}$ is the temperature-independent pre-exponential factor, $E_{a}$ is the apparent activation energy of the overall mineral fluid reaction, $\mathrm{R}$ is molar gas constant and $\mathrm{T}$ is temperature. Activation energy of the reaction can be obtained from the expression,

$$
\ln k=\ln \mathrm{A}-(\mathrm{E} / \mathrm{RT})
$$

as gradient of plot $\ln k$ versus $1 / \mathrm{T}$.

\section{Sample preparation}

Electron microprobe analysis of the stilbite sample (HTL 131), obtained from the British Geological Survey (BGS), Keyworth (U.K), on the basis of framework of 72 oxygen atoms gave the chemical composition shown in Table 1. The sample was crushed, ground in a mortar into fine powder grains and then sieved through a dry nylon sieve to obtain $125-250 \mu \mathrm{m}$ size fractions. The grains were pre-treated by washing them in alcohol for $1 \mathrm{~h}$, changing the cleaning solution every $5 \mathrm{~min}$, and then dried at $60{ }^{\circ} \mathrm{C}$ overnight. The geometric surface area of the grain was calculated assuming all the grains were of uniform size and has a regular spherical geometry. Taking $187.5 \mu \mathrm{m}$ as the diameter of the spherical

TABLE 1

Electron microprobe analysis of the stilbite (HTL131) sample used in this study

\begin{tabular}{lclc}
\hline Oxide & Weight\% of oxide & Ion & No ofions on the basis of framework of 72 oxygen \\
\hline $\mathrm{SiO}_{2}$ & 57.31 & $\mathrm{Si}$ & 27.64 \\
$\mathrm{Al}_{2}$ & 14.22 & $\mathrm{Al}$ & 8.08 \\
$\mathrm{Fe}_{2} \mathrm{O}$ & - & $\mathrm{Fe}$ & - \\
$\mathrm{FeO}$ & - & $\mathrm{Fe}$ & - \\
$\mathrm{MnO}$ & - & $\mathrm{Mn}$ & - \\
$\mathrm{MgO}$ & - & $\mathrm{Mg}$ & - \\
$\mathrm{CaO}$ & 8.47 & $\mathrm{Ca}$ & 4.40 \\
$\mathrm{SrO}$ & - & $\mathrm{Sr}$ & - \\
$\mathrm{BaO}$ & - & $\mathrm{Ba}$ & - \\
$\mathrm{NaO}$ & 1.53 & $\mathrm{Na}$ & 1.45 \\
$\mathrm{~K}_{2} \mathrm{O}$ & - & $\mathrm{K}$ & - \\
$\mathrm{H}_{2} \mathrm{O}$ & 18.49 & $\mathrm{H} 0$ & 30.12 \\
$\mathrm{Total}$ & 100.02 & & \\
\hline
\end{tabular}


grain and $2.16 \mathrm{~g} \mathrm{~cm}^{3}$ the density of stilbite (Breck, 1974) the specific surface area obtained was $0.0148 \mathrm{~m}^{\prime 2} \mathrm{~g}^{-1}$.

\section{Analyticalmethod}

Four sets of batch reactor experiments were performed at $4{ }^{\circ} \mathrm{C}, 25{ }^{\circ} \mathrm{C}, 40{ }^{\circ} \mathrm{C}$ and $60{ }^{\circ} \mathrm{C}$ using $p \mathrm{H}$ buffer solution with the $p \mathrm{H}$ ranging from 8.5 to 12.5 for each temperature. The buffer solutions shown in Table 2 were prepared using the recipes given by Perris and Dempsey, 1974. the reactors at specified times and acidified with $0.1 \mathrm{~mL}$ of concentrated $\mathrm{HNO}_{3}$ for $\mathrm{Si}$ analysis. $1 \mathrm{ml}$ of solution from the reactors was also taken during sampling for $p \mathrm{H}$ measurement to determine the stability of the buffer solution. The $p \mathrm{H}$ was measured immediately the solution had cooled to room temperature. The $p \mathrm{H}$ meter electrode was periodically calibrated against standard $p \mathrm{H}$ solutions $(p \mathrm{H} 4$ and $p \mathrm{H} \quad 7)$ at room temperature. The analytical uncertainty in the $p \mathrm{H}$ measurement was \pm 0.02 . The reaction

TABLE 2

Composition of reacting solution (Perris and Dempsey, 1974)

\begin{tabular}{lllll}
\hline $\mathrm{pH}$ & Buffer composition & \multicolumn{3}{c}{ Concentration (mol/L) } \\
& $A+B+C$ & $\mathrm{~A}$ & $\mathrm{~B}$ & $\mathrm{C}$ \\
\hline 8.5 & Boric acid+Potassium chloride+Sodium hydroxide & 0.05 & 0.05 & 0.010 \\
9.0 & Boric acid+potassium chloride+Sodium hydroxide & 0.05 & 0.05 & 0.021 \\
9.5 & Boric acid+Potassium chloride+Sodium hydroxide & 0.05 & 0.05 & 0.0346 \\
10.7 & Sodium borate+Sodium hydroxide & 0.0125 & & 0.0238 \\
11 & Sodium chloride+ sodium hydroxide & & 0.02 & 0.0015 \\
12 & Sodium chloride+ sodium hydroxide & & 0.02 & 0.0156 \\
12.5 & Potassium chloride+ sodium hydroxide & & 0.05 & 0.0408 \\
\hline
\end{tabular}

Each experiment utilised approximately $1 \mathrm{~g}$ of the prepared sample in $200 \mathrm{ml}$ of the $p \mathrm{H}$ buffered solution in plastic batch reactors maintained at the appropriate temperature to an accuracy of $\pm 1.0{ }^{\circ} \mathrm{C}$. The $4{ }^{\circ} \mathrm{C}$ experiment was carried out on a shaker, housed in a room maintained at $4{ }^{\circ} \mathrm{C}$ with liquid nitrogen. The 25,40 and $60 \mathrm{C}$ batch reactor experiments were carried out in preheated shaking waterbaths at atmospheric pressure. The agitation eliminated temperature gradient within the waterbaths and concentration gradients within the reacting solution in the reactors.

Throughout the experimental period, 10 $\mathrm{mL}$ of reacting solution was withdrawn from bottles were weighed before and after sampling. The headspaces of the reaction bottles were flushed with nitrogen gas after sampling to prevent uptake of $\mathrm{CO}_{2}$.

Silica analysis was carried out using Mackereth et al , 1978 method, which is based on the formation of a blue silicomolybdate complex and the measurement of the colour intensity on a single beam spectrophotometer. Silica standards solutions of 1, 5, 10, 25 and $50 \mathrm{mgl}^{-}$ were used for calibration. They were prepared with the buffer solutions $(p \mathrm{H}$ $8-12.5)$ to directly correct for any matrix interference effect from elements in the buffer solutions. Blanks were also prepared 
using the buffer solutions. A wavelength of $812 \mathrm{~nm}$ was used for the spectrometric reading. The uncertainty in measured $\mathrm{Si}$ concentrations was $\pm 3 \%$.

\section{Results}

Kinetic plots of the total released Si into the buffer solution against time profile (Ät/ÄV) are shown in Fig. 3ad. The time profile was measured for accuracy with volume correction made for any leakage or evaporation. The correction involved a differential of experimental run time against volume change. The dissolution rate was determined from the linear regions of the kinetic curves shown in Fig. 3 as far from equilibrium as possible, normalized to the calculated specific surface area of the grain. The dissolution rates are shown in Table 3 and graphically as the logarithm dissolution rate as a function of $p \mathrm{H}$ in Fig. 4. The dissolution rates increased with increasing $\mathrm{pH}$ and temperature from $3.45 \times 10^{\text {ss }}\left(\mathrm{mol} \mathrm{cm}^{2} \mathrm{~s}^{-1}\right)$ at $p \mathrm{H}$ 10.7 and $4{ }^{\circ} \mathrm{C}$ to $1.93 \times 10^{\circ}\left(\mathrm{mol} \mathrm{cm}^{2} \mathrm{~s}^{-}\right)$at $p \mathrm{H} 12$ and $60{ }^{\circ} \mathrm{C}$. The highest rate for the sample was recorded at $60{ }^{\circ} \mathrm{C}$ in the $p \mathrm{H} 12$ buffer solution. Dissolution rates were not obtained for the experiments carried out at $4{ }^{\circ} \mathrm{C}$ with $p \mathrm{H}$ less than 10.5 as the silica concentration was below detection limit.

Activation energy was estimated using the relation

$\operatorname{Ln}\left(\mathrm{R}_{2} / \mathrm{R}_{2}\right)=(\mathrm{E} / \mathrm{R})\left(1 / \mathrm{T}_{2}-1 / \mathrm{T}_{1}\right)$

where $\mathrm{R}_{i}$ and $\mathrm{R}$ are the dissolution rates at $p \mathrm{H}$ of interest and at temperatures $T_{1}$ and $T_{2}$ respectively and $\mathrm{R}$ is the molar gas constant. The activation energy value decreased from $48.45 \mathrm{~kJ} / \mathrm{mol}$ at $p \mathrm{H} 9$ to $30.88 \mathrm{~kJ} / \mathrm{mol}$ at $p \mathrm{H}$ 12.

The rate law established by fitting the logarithm dissolution rates to the $p \mathrm{H}$ values was

$$
\mathrm{R}=k\left(\mathrm{a}_{\text {oi }}\right)^{\prime},
$$

where $k$ is the rate constant, $a$ is the activity of the $\mathrm{OH}$ species and $\mathrm{n}$ the reaction order. The $\mathrm{n}$ values obtained were, 0.32 at $4{ }^{\circ} \mathrm{C}, 0.35$ at 25 $\mathrm{C}, 0.38$ at $40{ }^{\circ} \mathrm{C}$ and 0.38 at $60{ }^{\circ} \mathrm{C}$. The $\mathrm{n}$ values did not compare well with values obtained for stellerite, a zeolite of the stilbite family, which was carried out under similar conditions (Glover \& Faanu, 2007). The $\mathrm{n}$ values obtained for stellerite were 0.24 at 25 $\mathrm{C}, 0.33$ at $40^{\circ} \mathrm{C}$ and 0.42 at $60^{\circ} \mathrm{C}$. This may be due to the effect of the buffers to keep the $p \mathrm{H}$ constant (Chen \& Brantley, 1998). Increase in $\mathrm{n}$ values with temperature agrees with the surface protonation model that $p \mathrm{H}$ dependence of mineral dissolution increases with temperature at $p \mathrm{H}<p \mathrm{H}_{p m x}$ or $p \mathrm{H}>p \mathrm{H}_{p a x}$, (Chen \& Brantley, 2000).

The variation of $n$ with the reciprocal temperature in Kelvin was also determined (Fig. 5). The linearity of the graph as a function of the inverse of temperature indicates an Arrhenius relation, decreasing linearly with the inverse of temperature. Values of $\mathrm{n}$ in situ $\mathrm{pH}$ of the solutions at 4, 40 and $60{ }^{\circ} \mathrm{C}$ were evaluated from the values measured at $25{ }^{\circ} \mathrm{C}$ using the computer code EQ3NR version 7.0 (Worley, 1992).

\section{Discussion}

The kinetics of the dissolution of the sample was studied by following the release of Si into the buffer solutions. Deprotonation and formation of a precursor complex polarized and weakened the $\mathrm{Si}-\mathrm{O}$ bonds at the mineral surface, increasing the chance of silicon atoms entering into solution. The initial steep section of the kinetic curves (Fig. 3a-d) 


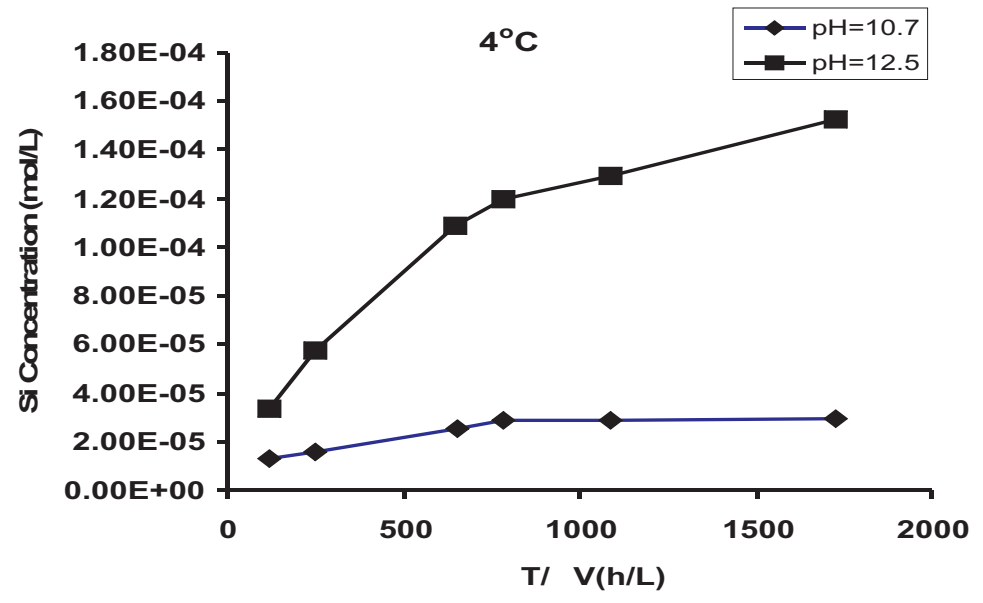

Fig. 3a. Silicon concentration (mol/l) as a function of the time profile (DT/DV) at $4{ }^{\circ} \mathrm{C}$

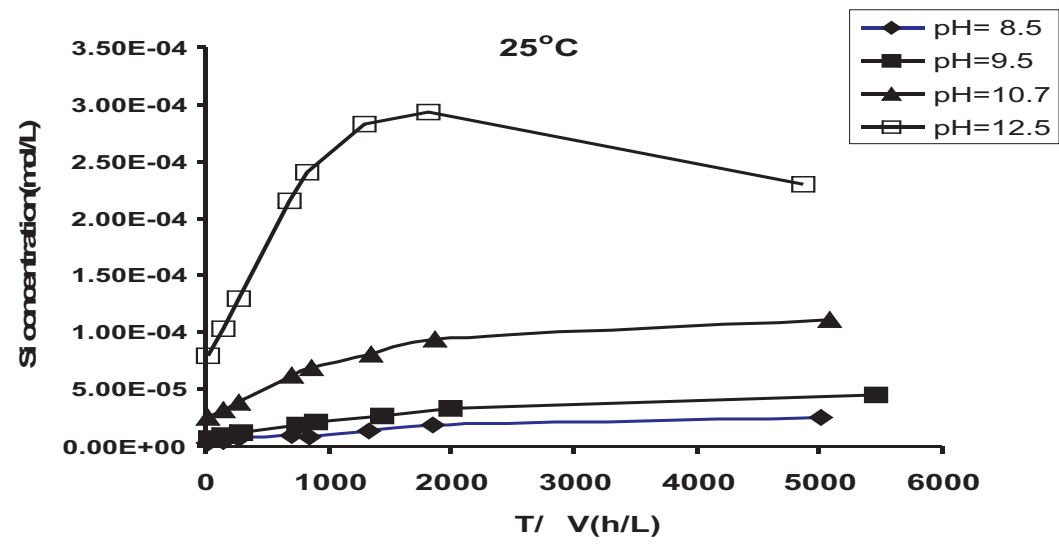

Fig. 3b. Silicon concentration $(\mathrm{mol} / \mathrm{l})$ as a function of the time profile (DT/DV) at $25{ }^{\circ} \mathrm{C}$

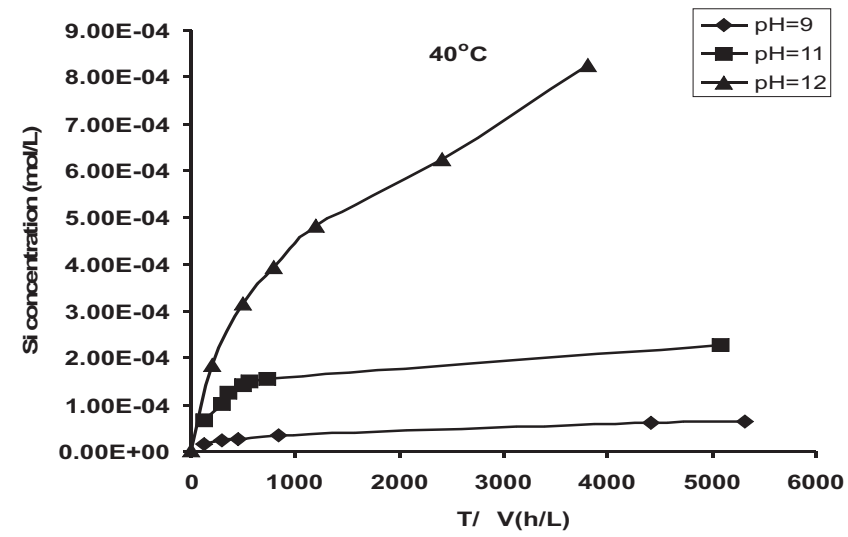

Fig. 3c. Silicon concentration $(\mathrm{mol} / \mathrm{l})$ as a function of the time profile (DT/DV) at $40{ }^{\circ} \mathrm{C}$ 
TABLE 3

Summary of the dissolution rates of stilbite (HTL 131)

\begin{tabular}{|c|c|c|c|c|}
\hline Temp. ${ }^{\circ} \mathrm{C}$ & pHnominal & Adjusted $p H$ & $\begin{array}{l}\text { Si dissolution rate } \\
(\mathrm{mol} / \mathrm{cm} / \mathrm{s})\end{array}$ & $\begin{array}{l}\log _{\text {in }} \text { i dissolution rate } \\
\left(\mathrm{mol} / \mathrm{cm}^{2} / \mathrm{s}\right)\end{array}$ \\
\hline 4 & 10.7 & 11.04 & $3.45 \mathrm{E}-15$ & -14.461 \\
\hline 4 & 12.5 & 13.35 & $1.87 \mathrm{E}-14$ & -13.728 \\
\hline 25 & 8.49 & 8.49 & $1.18 \mathrm{E}-15$ & -14.92 \\
\hline 25 & 9.52 & 9.52 & $2.25 \mathrm{E}-15$ & -14.65 \\
\hline 25 & 10.68 & 10.68 & $7.69 \mathrm{E}-15$ & -14.11 \\
\hline 25 & 12.59 & 12.59 & $3.02 \mathrm{E}-14$ & -13.52 \\
\hline 40 & 9 & 8.92 & 7.02E-11 & -10.15 \\
\hline 40 & 11 & 10.65 & $2.98 \mathrm{E}-10$ & -9.53 \\
\hline 40 & 12 & 11.87 & $9.46 \mathrm{E}-10$ & -9.02 \\
\hline 60 & 9 & 8.85 & $2.15 \mathrm{E}-10$ & -9.67 \\
\hline 60 & 11 & 10.14 & $3.98 \mathrm{E}-10$ & -9.40 \\
\hline 60 & 12 & 11.35 & $1.93 \mathrm{E}-09$ & -8.71 \\
\hline
\end{tabular}

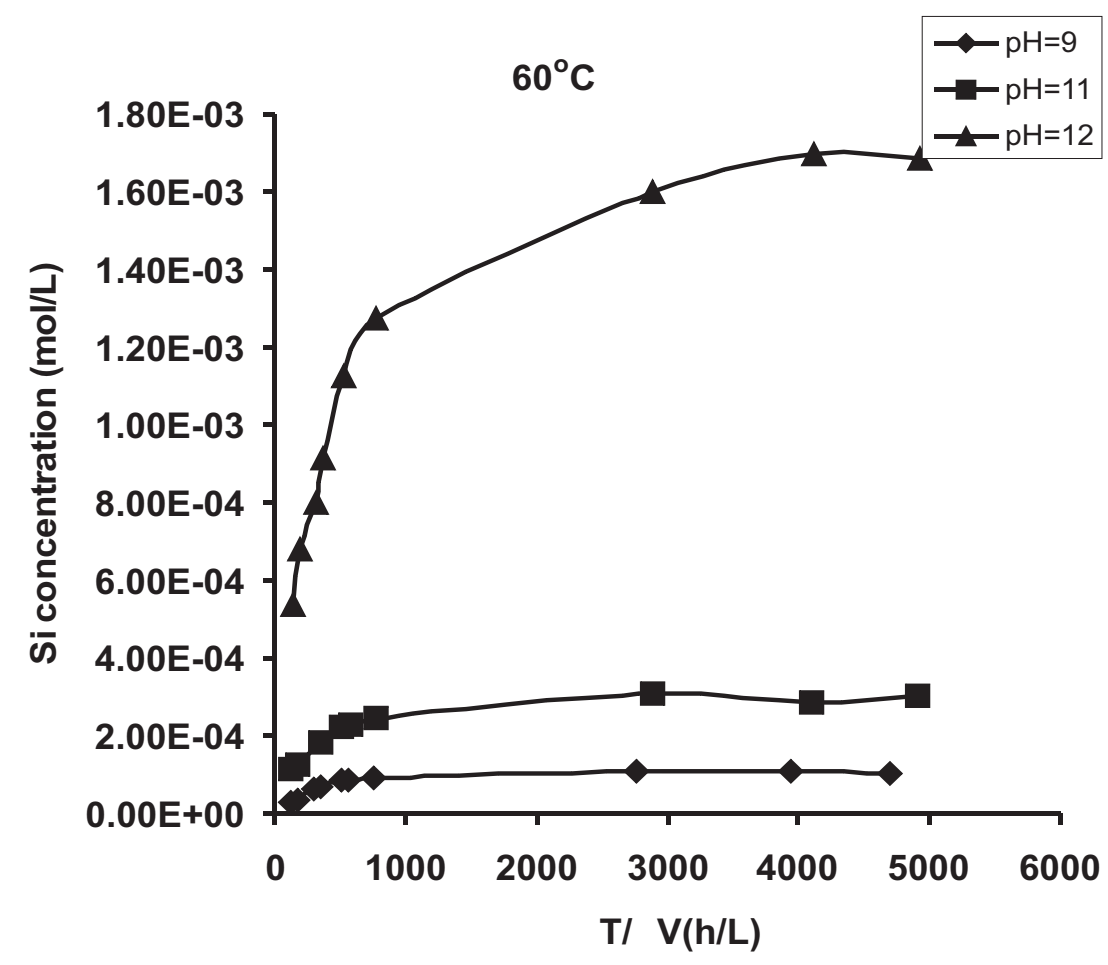

Fig. 3d. Silicon concentration (mol/l) as a function of the time profile (DT/DV) at $60{ }^{\circ} \mathrm{C}$ 


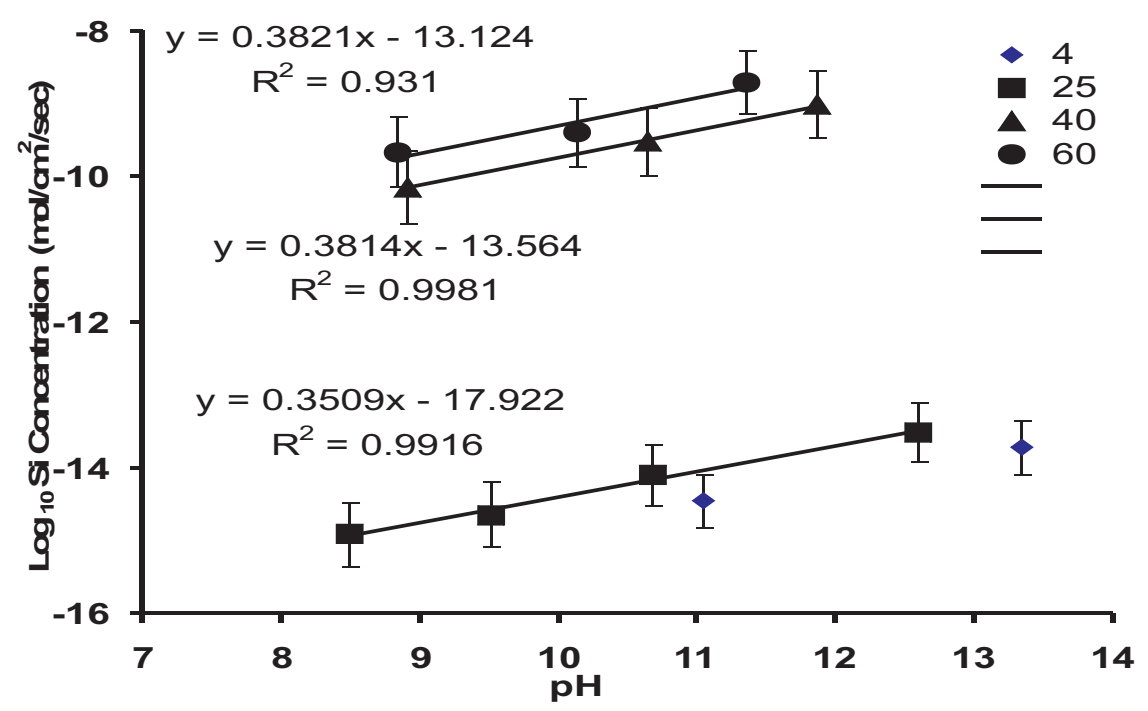

Fig. 4. Rate of stilbite dissolution at variable temperatures and in situ $p \mathrm{H}$ based on $\mathrm{Si}$ release

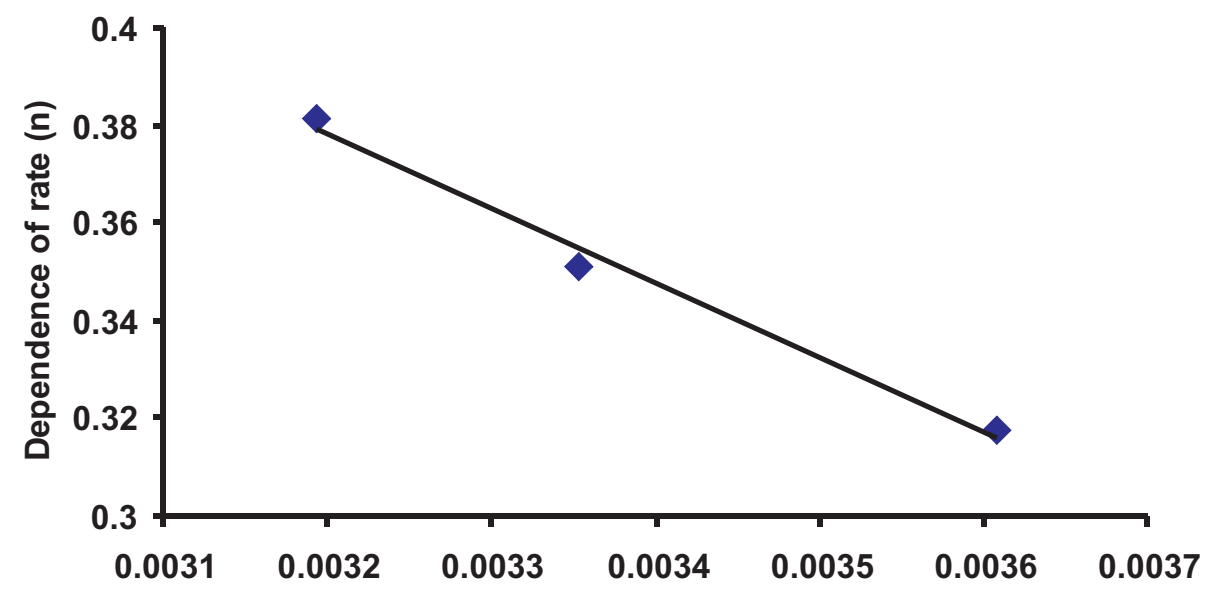

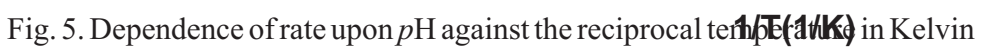

represented a faster dissolution process due to dissolution of the fine-grained materials from the crushing process, thin edges or corners on the grains (Huertas et al, 1999). The $\mathrm{Si}$ concentrations then increased at relatively constant rate before the curve flattened out, approaching steady state equilibrium. Taking samples from the reaction bottles reduced the volume of reacting solution, and moving the system close towards equilibrium and, thereby, slowing the dissolution rates. Weighing the bottles before and after sampling allowed for volume correction and any leakage or evaporation to be accounted for. The correction involved a differential of experimental run time against volume change ( $\ddot{\mathrm{A}} \mathrm{t} / \mathrm{A} \mathrm{V})$ as outlined by Bevan etal., 1989. 
The effect of the temperature on the dissolution rates is a function of the activation energy $\mathrm{Ea}$, expressed by the Arrhenius equation:

$$
\mathrm{k}=\mathrm{A}^{\operatorname{manr}}(6)
$$

where Ea represents an apparent activation energy and $\mathrm{A}$ is the pre-exponential factor. Increase in temperature increased the energy in the reacting solution, expressed as an increase in the number of molecules that can potentially exceed the activation energy and form dissolution precursor complexes and, consequently, increase the dissolution rates. Increase in temperature increased the $n$ values slightly $(0.33,0.35,0.38$, and 0.38$)$, but the values were the same within statistical range and, therefore, showed little temperature dependence of the reaction order within the temperature range. The dissolution rate increased with temperature and $p \mathrm{H}$, however, activation energy decreased with increase in $p \mathrm{H}$. This may be due to data spread.

According to Huertas et al., 2001, activation energy is influenced by the contribution of the enthalpy of adsorption phenomena and may result in the variation in activation energy with $p \mathrm{H}$. There was nondetection of Si release at $p \mathrm{H}$ lower than 10.5 at $4{ }^{\circ} \mathrm{C}$ because at near neutral $p \mathrm{H}$ dissolution rates of minerals containing isolated silica tetrahedra have lower site potentials and have substantially larger temperature dependency ( Brady \& Walther, 1992).

Compared with other aluminosilicates data found in journals, stilbite had similar dissolution rates with stellerite and illite at 25 C under alkaline conditions but had higher dissolution rates than quartz, heulandite and anorthite, and lower dissolution rates than kaolinite (Fig. 6).

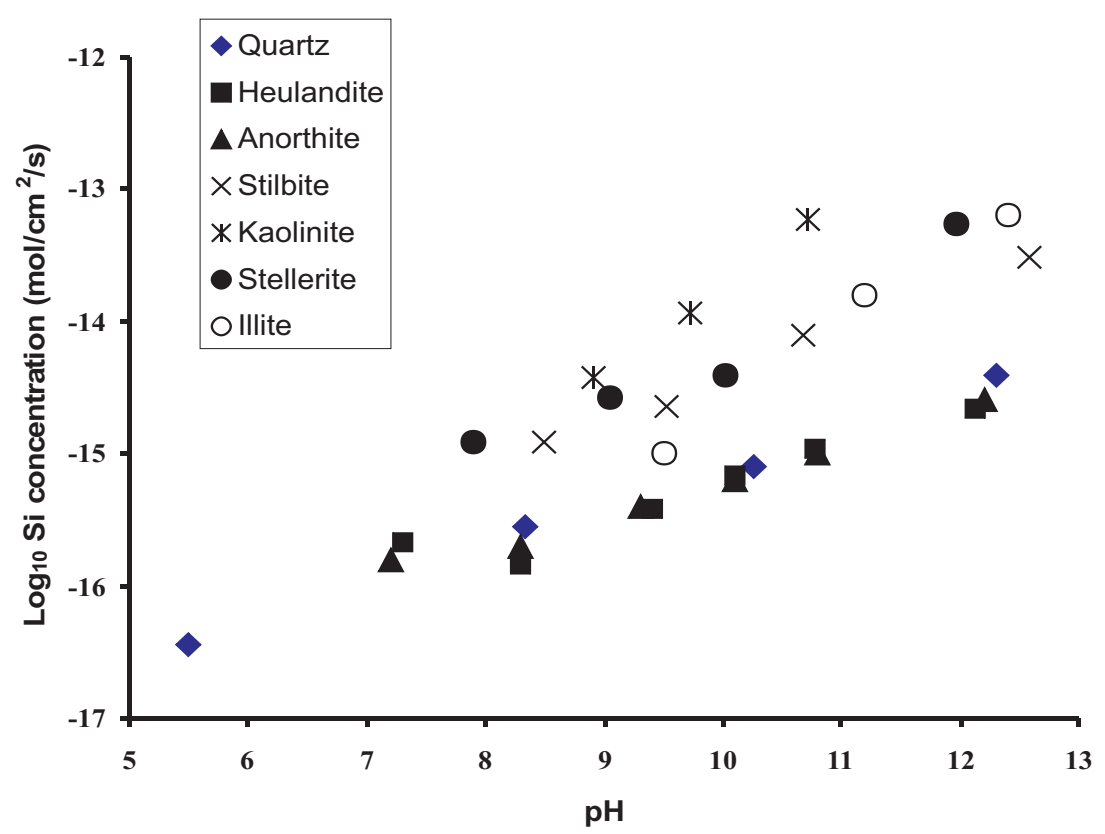

Fig. 6. Comparison of stilbite dissoultion rates at $25{ }^{\circ} \mathrm{C}$ obtained in this study with dissolution rates of other aluminosilicates available in literature. Data from other studies are: analcime (Savage, 2001), heulandite(Ragnarsdottir,1993), anorthite (Brady et al.,1989), quartz(Brady and Walther,1990) and illite(Kohler et al., 2003). 


\section{Conclusion}

The rate of dissolution increased with temperature and $p \mathrm{H}$ from $3.45 \times 10$ ss $\left(\mathrm{mol} \mathrm{cm}^{2}\right.$ $\left.\mathrm{s}^{-1}\right)$ to $1.93 \times 10^{\circ}\left(\mathrm{mol} \mathrm{cm}^{2} \mathrm{~s}^{-1}\right)$. The dissolution behaviour of stiblite was similar to other aluminosilicates. At constant temperature, increasing the $p \mathrm{H}$ increased dissolution rate, where as at constant $p \mathrm{H}$, dissolution rate increased with temperature. A good linear relationship was established between logarithm dissolution rate and solution $p \mathrm{H}$. The reaction order $\mathrm{n}$ increased slightly with increasing temperature. The apparent activation energy was not dependent on $p \mathrm{H}$ as it decreased with increase in $p \mathrm{H}$. More experiments using stilbite at different temperatures will give a clearer picture of the variation of rate $p \mathrm{H}$ dependency with temperature.

\section{Acknowledgement}

The authors would like to thank Dr Liz Bailey of the University of Nottingham as well as Dr Chris Rochelle and Keith Bateman of British Geological Survey, Keyworth, for their immense support, ideas and assistance in carrying out the study. They also thank John Corrie and Darren Hepworth for monitoring the temperature of the waterbaths.

\section{References}

Bevan J. and Savage D. (1989). The effect of organic acids on the dissolution of K-feldspar under conditions relevant to burial diagenesis. Mineralog. Mag. 53: 415-425.

Brady P. and Walther J. V. (1989). Controls of silicate dissolution rates in neutral and basic $p \mathrm{H}$ solutions at 25 C. Geochim. Cosmochim. Acta. 53: 2823-2830.

Brady P. and Walther, J. V. (1990). Kinetics of quartz dissolution at low temperatures. Chem. Geol. 82: 253-264.

Brady P. and Walther J. V. (1992). Surface chemistry and silicate dissolution at elevated temperatures.
Amer. J. Sci. 292, pp 639-658.

Breck D. W. (1974). Zeolite Molecular Sieves: Structure, Chemistry, and Use. John Wiley \& Sons, New York, 771pp.

Chen Y. and Brantley S. L. (1998). Diopside and anthophyllite dissolution at $25{ }^{\circ} \mathrm{C}$ and $90{ }^{\circ} \mathrm{C}$ and acid $p$ H., Chem. Geo. vol. 147, pp 233-248 .

Chen Y and Brantley S. L. (2000). Dissolution of forsteritic olivine at $65^{\circ} \mathrm{C}$ and $2<p \mathrm{H}<5$. Chem. Geol. 165: 267-281.

Glover E. T. and Faanu A. (2007). Stellerite dissolution kinetics under hyperalkaline conditions. J. Appl. Sci Tech. 12(1\&2): 25-30.

Hodgkinson E. S. and Hughes C. R. (1999). The mineralogy and geochemistry of cement/rock reactions: high-resolution studies of experimental and analogue materials, Geo. Soc., Lond. 157:195-211.

Huertas F. J. Chou L. and Wollast R. (1999). Mechanism of Kaolinite Dissolution at Room Temperature and Pressure, Part II: Kinetics Study. Geochim. Cosmochim. Acta 63: 3261-3275.

Kohler S. J. Dufaud F. and Oelkers E. H. (2003). An experimental study of illite dissolution kinetics as a function of $p \mathrm{H}$ from 1.4 to 12.2 and temperature from 5 to 50 C. Geochim. Cosmochim. Acta 67: 3583-3594.

Mackereth F. J. H. Heron J. and Talling J. F. (1978). Water analysis: some revised methods for limnologists: Freshwater Biological Association Scientific publication n. 36, Cumbria and Dorser, England, $120 \mathrm{pp}$.

Perris D. D. and Dempsey B. (1974). Buffers for $\mathrm{pH}$ and metal ion control. John Wiley \& Sons, New York, $171 \mathrm{pp}$.

Quartieri S. and Vezzalini G. (1987). Crystal chemistry of stilbites: structure refinements of one normal and four chemically anomalous samples, Zeolites. 7: 163-170.

Ragnarsdottir K. V. (1993). Dissolution kinetics of heulandite at $p \mathrm{H} 2-12$ and $25{ }^{\circ} \mathrm{C}$. Geochim. Cosmochim. Acta 57: 2439-2449.

Savage D. (1996). Zeolites occurances, stability and behaviour; a contribution to phase III of the Jordan Natural Analogue Project QuantiSci. DoE Report No DOE/HMIP/RR/95.020.

Savage D. Rochelle C. Moore Y. Milodowski A. Bateman K. Bailey D. and Mihara M. (2001). 
Analcime reactions at $25-90{ }^{\circ} \mathrm{C}$ in hyperalkaline fluids. Mineralog. Mag. 65(5): 571-587.

Wieland E. Wehrli B. and Stumm W. (1988). The coordination chemistry of weathering: III A generalization on the dissolution rates of minerals. Geochim. Cosmochim. Acta 52: 1969-1981.
Wolery T. J. (1992). EQ3NR, A Computer Program for Geochemical Aqueous Speciation-Solubility Calculations: Theoretical Manual, User's Guide, and Related Documentation (Version 7.0). Lawrence Livermore National Lab.UCRL-MA110662-PTIV. 